\title{
CLINICAL FEATURES POST-VACCINATION MENINGOENCEPHALITIS IN CHILDREN WITH CONVULSIVE DISORDERS
}

\author{
Sadikova G.K., *Berdieva H.U.
}

Tashkent Pediatric Medical Institute, Department of Neurology, Pediatric Neurology, Tashkent, Uzbekistan

Keywords: convulsive disorders, post-vaccination meningoencephalitis.

Among all acute viral neuro-infections share of post-vaccination encephalitis is about $20 \%$ [1], and the incidence in the world of e ranges from 3.9 to 7.5 per 100000 child population [6]. It is known that even ended favorably post-vaccination meningoencephalitis rarely leaves the subsequent neurological defect in children with cognitive impairment [4]. In the period of convalescence meningoencephalitis remains high risk of developing symptomatic epilepsy. This is due to a local necrotic process mainly in the gray matter of the brain with the formation of structural defects which may cause the formation of a persistent focus of pathological activity in the residual period. [2].

All this suggests the need to study the clinical and paraclinical features post-vaccination meningoencephalitis in children with symptomatic epilepsy.

Objective. To study the clinical and paraclinical features post-vaccination meningoencephalitis in children.

Materials and methods. Observation group consisted of 30 children: 19 girls and 11 boys (mean age $4.9 \pm 1.2$ years). Scheme of reference of sick children included clinical neurological monitoring in acute disease during finding children in the hospital, and dynamics. The examination of sick children underwent clinical, neurological, laboratory, instrumental (NSG, EEG, CT/MRI) examination.

Duration of focal neurological symptoms over 3 days was the leading diagnostic criteria of post-vaccination syndrome meningoencephalitis. Clinical and neurological examination included history (epidemiologic, and life history of the disease), clinical somatic and neurological examinations.

Results. According to our data, we established that post-vaccination meningoencephalitis occurs in children with a history of premorbid back* e-mail: xilola.kabirova.89@mail.ru ground (rickets $32 \%$ ), malnutrition (13.3\%), anemia $(90 \%)$, somewhat of an illness, SARS frequent $(40 \%)$ that in turn contributed to the overall reactivity and sensitization.

On average, post-vaccination meningoencephalitis developed by $3.2 \pm 0.09$ after DTP and leaking expressed intoxication. All children observed drowsiness fever, general weakness, moodiness, against which any cramps, and wore a generalized tonic-clonic in nature $20 \%$ of consciousness. Impaired consciousness was one of the early signs of nervous system involvement in the pathological process. In accordance with the scale of Glasgow were reported different levels of impaired consciousness. Degree of impairment of consciousness on the Glasgow Coma Scale in children with post-vaccination meningoencephalitis averaged $22.9 \pm 0.9$ points.

In the neurological status of all children observed clearly marked meningeal symptoms of various origins. Of focal symptoms was a weak response to light $(70 \%)$, anisocoria, the unevenness of the optic fissure $(47 \%)$, increased tendon reflexes $(80 \%)$. In all patients, abdominal reflexes are not invoked. Spastic hemiparesis, Babinski, Oppenheim ascertained in $73.3 \%$ of cases. The rest of the children observed asymmetry of skin, tendon and periosteal reflexes picture with severe cerebral symptoms.

In the study of peripheral blood was marked leukocytosis $14.6 \pm 1.210 .9 \mathrm{x} / 1$ and neutrocytosis $10.3 \pm 0.8 \times 10$ 9/1, accelerated ESR-14-20ml.1ch. In $73.3 \%$ of patients in the EEG in various forms showing interest Meso-diencephalic structures: generalized outbreak Д-, И-waves and proximal digits: paroxysmal outbreaks bilateral, synchronized activity, mostly expressed in the frontocentral regions of the hemispheres. In $16.7 \%$ of patients in the EEG observed diffuse depression bioelectrical (б-like fluctuations И), against which recorded average $\mathbf{B}$ wave frequency and low 
amplitude.

When CT/MRI of the brain in only 12 of the 30 children studied were observed focal changes in the temporal and frontal lobes of the brain. We identified eight signs of deformation: expansion of the lateral ventricles and their asymmetry in 4 children, expansion of subarachnoid space in 4. Cystic changes in the subarachnoid space 2 persons.

Thus, the speed and severity of symptoms developing cerebral vascular explained pronounced participation factor and progressive brain edema.

\section{REFERENCES}

1. Demkina V.A. Acute viral encephalitis in children: clinical and immunological aspects: Dis. ...cand. of med. sciences - Moscow, 2008. 105 p.

2. Zavodnova O.S., Bezrodnova S.M., Horev O. Liquorologic and neurosonographic characteristic combined meningoencephalitis (Toxoplasma+virus+bacteria) / Jubilee International Scientific and Practical Conference "Modern scientific and practical problems of infectious diseases in children". - St. Petersburg, 2003. - P. 48-49.

3. Leschinskaya E. Acute viral encephalitis in children / E.V. Leschinskaya, J.H. Martynenko. - M. GEOTAR
Conclusion. In children post-vaccination meningoencephalitis characterized by a high frequency of involvement in the pathological process of the meninges and the solid matter of the brain.

For acute post-vaccination period meningoencephalitis in children is characterized by the presence of cerebral and focal neurological symptoms. Instrumental studies in acute CNS disease reveals abnormalities inflammatory character of varying severity, which requires a more responsible attitude when conducting DPT vaccinations in children.

Media, 2005. - 356.

4. Pokrovsky V.I., Lobzin Y.V., Volzhanin V.M. Beloserov E.S., Bulankov Y.I. Infection of the nervous system with a progressive course. - St. Petersburg.: Folio, 2007. - 263 p.

5. Sorokina, M.N., Scripcenco N.V. Viral encephalitis and meningitis Children: A Guide for Physicians. - Moscow, Medicine, 2004 - S. 260-305.

6. Delhaye S., Paul S., Blakqori G., Minet M., et al. Neurons produce type I infection during viral encephalitis / Proceedings of the National Academy of Sciences of the USA. - 2006. - Vol 103, N20. - p. 7835-40.

\title{
XÜLASə
}

\section{QICOLMA SINDROMU OLAN USSAQLARDA POSTVAKSINAL MENINQOENSEFALITIN KLINN OLAMӘTLORI}

\author{
Sadikova Q.K., Berdiyeva H.U. \\ Daşkənd pediatrik tibb institutunun nevrologiya, uşaq nevrologiyası kafedrası, Daşkənd, Özbəkistan
}

Q1colma sindromu olan uşaqlarda qızılça meninqoensefalitinin kəskin dövrü üçün nevroloji əlamətlərin politopikliyi xarakterdir. Mərkəzi sinir sisteminin morfofunksional instrumental tədqiqatları kəskin dövrdə müxtəlif xarakterə və qabarıqlıq səviyyəsinə malik patoloji dəyişikliklər təsbit edir ki, bunlar da uşaqlarda q1zılça meninqoensefaliti zamanı serebral disfunksiyanın diaqnostik əhəmiyyətli erkən əlamətlərini aşkarlamağa kömək edir.

Açar sözlər: postvaksinal meninqoensefalit, qıcolma sindromu. 


\title{
PЕЗЮМЕ
}

\section{КЛИНИЧЕСКИЕ ПРИЗНАКИ ПОСТВАКЦИНАЛЬНОГО МЕНИНГОЭНЦЕФАЛИТА У ДЕТЕЙ С СУДОРОЖНЫМ СИНДРОМОМ}

\author{
Садикова Г.К., Бердиева Х.У. \\ Ташкентский педиатрический медицинский институт, кафедра неврологии, \\ детской неврологии, Ташкент, Узбекистан
}

Для острого периода коревых менингоэнцефалитов у детей с судорожным синдромом характерна политопичность неврологических проявлений. Морфофункциональные инструментальные исследования центральной нервной системы в остром периоде выявляют патологические изменения различного характера и степени выраженности, что позволяет обнаружить ранние диагностически значимые признаки церебральной дисфункции при коревых менингоэнцефалитах у детей.

Ключевые слова: поствакцинальный менингоэнцефалит, судорожный синдром.

Redaksiyaya daxil olub: 03.09.2014

Çapa tövsiya olunub: 01.10.2014

Rəyçi: t.ü.f.d., Sadlxova Z.M. 